Tijana V. Đurđević, Ph.D. Student

University of Novi Sad

Faculty of Law Novi Sad

durdevict@yahoo.com

\title{
IS DNA ANALYSIS THE KEY TO FREEING THE WRONGFULLY CONVICTED?*
}

\begin{abstract}
The fact that nearly five hundred wrongfully convicted persons have been exonerated thanks to subsequent DNA analysis, after the discovery of DNA and the possibility of identifying person on the basis of DNA, inspired us to research the issue of wrongful convictions and the role of DNA analysis in their correction. This paper firstly discusses the concept and consequences, the estimates of frequency and the causes of wrongful convictions. After that, it gives an overview of some organizations that deal with cases of wrongful convictions in comparative practice. It further explains the role of DNA in exonerations of the wrongfully convicted as well as the assumptions that must exist in order to correct the conviction this way. Lastly, the paper discusses current possibilities and prospects in the Republic of Serbia regarding the correction of the wrongful convictions through subsequent DNA analysis and in other ways.
\end{abstract}

Keywords: criminal procedure, wrongfully convicted, DNA, the innocence projects.

\section{INTRODUCTION}

When a 20 -year-old girl was raped and murdered in Austin, Texas in October 1988, two roommates - Christopher Ochoa and Richard Danziger - were arrested. ${ }^{1}$

* The paper is written within the project „Human Rights and Values in Biomedicine - Democratization of decision-making and implementation in health care" (Project No. 179023), funded by the Ministry of Education, Science and Technological Development

${ }^{1}$ Ellen Yaroshefsky, „Ethics and Plea Bargaining - What's Discovery Got to Do With It”, Criminal Justice 28/2008, 29; Steven A. Krieger, „Why Our Justice System Convicts Innocent People, and the Challenges Faced by Innocence Projects Trying to Exonerate Them", New Criminal Law Review 14(3)/2011, 347; Daniel S. Medwed, Prosecution Complex: America's Race to 
According to Ochoa, ${ }^{2}$ he knew nothing about this crime, but while being interrogated by the police, he was threatened with a death penalty if he did not cooperate. ${ }^{3}$ His mother also received calls and threats that her son would be executed if he did not confess to the crime. Ochoa, feeling pressured and trying to avoid the death penalty, pleaded guilty to murder and agreed to testify against Danziger on court. The only evidence against Danziger, other than this testimony, was the pubic hair found at the crime scene, which was allegedly consistent with Danziger's. A small amount of semen was also found, however, it was not possible to determine to whom the semen belonged. Danziger was convicted of rape. Both of them were given a life sentence.

Achim Josef Marino was a convict serving three life sentences in Texas in the 1990s who became a "born-again Christian" in prison. In 1998, this convict wrote a letter to the former President of the United States, George Bush, in which he confessed that he alone committed the rape and the murder for which Ochoa and Danziger were convicted. In addition to the confession, he also sent information on where the evidence could be found. The police reopened the investigation. With the help of the Wisconsin Innocence Project, a DNA testing of the biological traces from the crime scene was performed and the results confirmed Marino's confession. Ochoa and Danziger were released in 2002 after spending 12 years in prison.

\section{THE CONCEPT AND CONSEQUENCES OF WRONGFUL CONVICTIONS}

Part of the literature underlines the difference between the actual ${ }^{4}$ or factual ${ }^{5}$ innocence and the wrongful conviction ${ }^{6}$ or miscarriage of justice ${ }^{7}$. A person is

Convict, and Its Impact on the Innocent, New York 2012, 54; Richard Danziger, https://www.law. umich.edu/special/exoneration/Pages/casedetail.aspx?caseid=3152, April 3, 2019.

${ }^{2}$ America's Guilty Plea Problem: Chris Ochoa, https://www.youtube.com/watch? $v=A U 65911-B b U$, April 3, 2019.; Chris Ochoa: A True Story of a False Confession, https://www.youtube.com/watch?v =9aI8AqB_TLA, April 3, 2019.; Innocence Project - Chris Ochoa, https://www.youtube.com/ watch? $v=\overline{0 x} J l s x C G w 9 w$, April 3, 2019.

${ }^{3}$ Taking Ochoa's hand and pointing to his vein, the police officer said: „This is where the needle is gonna go if you do not cooperate and tell us." America's Guilty Plea Problem: Chris Ochoa, https://www.youtube.com/watch? $v=A U 65911-B b U$, April 3, 2019.

${ }^{4}$ Gwendolyn Carroll, ,Proven Guilty: An Examination of the Penalty-Free World of PostConviction DNA Testing”, The Journal of Criminal Law and Criminology 97(2)/2007, 672

${ }^{5}$ Jon B. Gould, Richard A. Leo, „One Hundred Years Later: Wrongful Convictions after a Century of Research", The Journal of Criminal Law and Criminology 100(3)/2010, 832

${ }^{6}$ G. Caroll, 672

${ }^{7}$ Stephanie Roberts, Lynne Weathered, „Assisting the Factually Innocent: The Contradictions and Compatibility of Innocence Projects and the Criminal Cases Review Commission", Oxford Journal of Legal Studies 29(1)/2009, 50 
factually innocent if it did not commit a crime, while a wrongful conviction implies that a person has been convicted despite some procedural error due to which it should not have been convicted. Therefore, wrongful conviction involves a convicted person who may or may not be factually innocent. It should be noted that the aforementioned conceptual differences are not accepted all without exception in the literature and that some authors ${ }^{8}$ and statistics ${ }^{9}$ speak of wrongful convictions or miscarriages of justice taking into account only the convictions of persons who did not commit the crime for which they were convicted.

Apparently, the consequences of convicting the truly innocent cannot be compared to the consequences of wrongful convictions which occur as the result of procedural mistakes. As long as an innocent person is behind bars, the society is at risk because the actual perpetrator is still at large. Also, a wrongfully convicted person loses its freedom and faces the dangers of prison life. ${ }^{10}$ Having that in mind, in this paper, the concept of "wrongful convictions" is used for convictions of actually innocent persons.

\section{ESTIMATING THE PREVALENCE OF WRONGFUL CONVICTIONS}

Criminal proceedings are guided by the principle that no innocent should be convicted..$^{11}$ Further, an English lawyer, William Blackstone ${ }^{12}$ is famous for his quote that "it is better that ten guilty persons escape than that one innocent suffer." Except in cases where it later turns out that the crime was not committed at all, for example, because the victim of the alleged murder was found alive and well, we can never be completely sure that we know the truth about the crime and the perpetrator. ${ }^{13}$ Therefore, it is impossible to determine how many convicted persons are actually innocent.

${ }^{8}$ See Robert J. Norris, „Framing DNA: Social Movement Theory and the Foundations of the Innocence Movement", Journal of Contemporary Criminal Justice 33(1)/ 2017, 39; Lynne Weathered, „Investigating Innocence - The Emerging Role of Innocence Projects in the Correction of Wrongful Conviction in Australia", Griffith Law Review 12(1)/2003, 85; S. Krieger, 360

9 The National Registry of Exonerations, http://www.law.umich.edu/special/exoneration/ Pages/Race-and-Wrongful-Convictions.aspx, April 3, 2019.; List of miscarriage of justice cases, https://en.wikipedia.org/wiki/List_of_miscarriage_of_justice_cases, April 3, 2019.

10 J. Gould, R. Leo, 836

${ }^{11}$ See Criminal Procedure Code - CPC, Službeni glasnik RS, no. 72/2011, 101/2011, 121/2012, 32/2013, 45/2013 and 55/2014, art. 1

${ }^{12}$ Sir William Blackstone, https://www.britannica.com/biography/William-Blackstone, April 3, 2019.

${ }^{13}$ Chrisje Brants, „Vulnerability of Dutch Criminal Procedure to Wrongful Conviction”, Wrongful Conviction: International Perspectives on Miscarriages of Justice (eds. Ronald C. Huff, Martin Killias), New York 2013, 158 
Nevertheless, different estimates can be found in the literature. The death penalty opponents recorded 350 cases of wrongful convictions for the most serious crimes in the United States from 1900 to $1985 .{ }^{14}$ One study found that the minimum rate of wrongful convictions for capital rape-murder in the US in the 1980s amounted to $3.3 \% .{ }^{15}$ It is estimated that $4.1 \%$ of criminal defendants who received a death sentence between 1973 and 2004 in the US were wrongfully convicted. ${ }^{16}$ The percentages of all wrongfully convicted to life imprisonment in the US ranges from 0.5 to $5 .{ }^{17}$ On the other hand, placing American experience over the last 15 years (20 exonerations of wrongfully convicted per year) into European frameworks, some estimations point to 7 wrongful convictions per year in Germany and 5 in France. ${ }^{18}$ Data also reveal a total of 3218 non-US cases of wrongful convictions by $2018 .{ }^{19}$

When it comes to the Republic of Serbia, just because there is no empirical study on wrongful convictions it does not mean that one can speak of a flawless judiciary. Namely, if the wrongfully convicted person is the one who has been finally convicted of a criminal offense that it did not do, then the statistics regarding the extraordinary legal remedy - request for reopening criminal proceedings can serve as a factor in assessing whether a final conviction was right or wrong. The study of the practice of the Basic Court in Niš in the period from the beginning of 2014 to the end of 2016 in cases in which a request for reopening criminal proceedings was filed shows that (only before this court and only in mentioned time range) there was one request which, after it was granted, resulted in dismissing the indictment, instead of the previously imposed sentence of 5 months and 7 days. ${ }^{20}$ During the same period, the Higher Court in Niš received a request for reopening criminal proceedings, which, upon being granted, resulted in the reversal of the judgment. ${ }^{21}$ The defendants in both cases were wrongfully convicted pending the annulment of the previous judgments.

\footnotetext{
${ }^{14}$ Hugo Adam Bedau, Michael L. Radelet, „Miscarriages of Justice in Potentially Capital”, Stanford Law Review, 40(1)/1987, 38

${ }^{15}$ Michael D. Risinger, „Innocents Convicted: An Empirical Justified Factual Wrongful Conviction Rate" The Journal of Criminal Law \& Criminology 97(3)/2007, 762

${ }^{16} \mathrm{~S}$. R. Grossa et al, ,Rate of false conviction of criminal defendants who are sentenced to death", PNAS, 11(20)/2014, 20

${ }^{17}$ L. Weathered, 65

${ }^{18}$ Ronald C. Huff, Martin Killias, „Wrongful Conviction: Conclusions from an International Overview", Wrongful Conviction: International Perspectives on Miscarriages of Justice (eds. Ronald C. Huff, Martin Killias), New York 2013, 296

${ }^{19}$ Innocents Database, http://forejustice.org/idbinternational.html, April 3, 2019.

${ }^{20}$ Ivan Ilić, Ispitivanje činjenične osnove krivične presude: doktorska disertacija, University of Niš, Faculty of Law, Niš 2018, 431

${ }^{21}$ Ibid., 433. Bearing in mind that this extraordinary legal remedy can only be filed in favor of the defendant, the conviction was evidently overturned and the defendant was acquitted.
} 
Having these assessments in mind, we can conclude that wrongful convictions are an international problem as well as the reality of criminal justice systems. Writing about the death sentence of Christian Ranucci (the last person executed in France), French writer Gilles Perrault said that the honor of justice consists of admitting that it may be wrong. ${ }^{22}$

Proponents of the death penalty downplayed the significance of wrongful convictions by making comparisons such as the following: "(trucks) run over innocent bystanders more frequently than courts sentence innocents to death. We do not give up trucks because the benefits they produce outweigh the harm, including the death of innocents." ${ }^{23}$ Although most countries have abolished the death penalty, the problem of wrongful convictions had not ceased to exist. States will not renounce trials simply because wrongful convictions happen. However, the causes of wrongful convictions and ways to minimize them ought to be taken into consideration.

\section{THE CAUSES OF WRONGFUL CONVICTIONS}

\subsection{Misidentification}

Identification of suspects is an unavoidable segment of numerous criminal investigations while witness testimony is the most commonly used evidence in criminal proceedings. ${ }^{24}$ As many as $70 \%$ of the 350 wrongful convictions that were overturned due to subsequent DNA analysis were caused by the witness's misidentification of the perpetrator. ${ }^{25}$ Misidentification can be a consequence of psychological errors in human perception and memory, but also a consequence of the suggestiveness of the competent authorities during the identification process. ${ }^{26}$

Because our memories are not video recordings, ${ }^{27}$ they are often unreliable. In addition, stress changes one's understanding of events. The moment victims are faced with a weapon, they can place such focus on that weapon that they do not remember a single detail about the attacker, although the victims may later think they remember the attacker well. ${ }^{28}$ Furthermore, errors may be the result of various

${ }^{22}$ Gilles Perrault: "L'honneur de la justice est d'admettre qu'elle peut se tromper", https:// www.humanite.fr/node/241053, March 6, 2019.

${ }^{23}$ Ernest van den Haag, ,The Death Penalty Once More”, UC Davis Law Review 18(4)/1985, 967

${ }^{24}$ Adnan Fazlić, Irma Deljkić, ,Multidisciplinarni pristup provođenju radnje prepoznavanja osoba u kriminalističkoj istrazi”, Kriminalistička teorija i praksa 4(2)/ 2017, 41

${ }^{25}$ Eyewitness Misidentification, https://www.innocenceproject.org/causes/eyewitness-misidentification/, April 3, 2019.

${ }^{26}$ J. Gould, R. Leo, 841-43

${ }^{27}$ L. Weathered, 70

${ }^{28}$ J. Gould, R. Leo, 842 
suggestive actions by members of the competent authorities during any stage of the identification process,${ }^{29}$ which are aimed at steering the witness to identify the suspect as the perpetrator. ${ }^{30}$ The theory proposes that during the identification process, especially in pre-trial proceedings, attention should be paid to the following: ${ }^{31}$ if identification is being performed over photographs, then the photographs should be shown to the witness one by one (not together), and after the witness is shown each photograph, the witness should be asked whether it recognizes the perpetrator; the number of persons in a police lineup should be as high as possible; the member of the competent authorities present during the identification should not know the identity of the suspect; the time between the witness reports the crime and the suspect identification should be as short as possible; the identification process should be recorded to minimize suggestive behavior.

\subsection{Tunnel Vision}

In situations where both the criminal offense and the possible perpetrator are reported to the competent authorities, the investigating authorities may use all their resources to incriminate that suspect, overlooking not only evidence that indicates that the suspect is not the perpetrator, but also evidence that may incriminate someone else. In any investigation, there is a possibility that the competent authorities may assume that the suspect is guilty, and the stronger this belief is, there is less chance that competent authorities will consider any other possibility. ${ }^{32}$ When investigative authorities are focused on the individual, the investigation is often not conducted objectively, the time since the commission of a criminal offense passes by, and the true perpetrator is provided an opportunity to hide evidence - all of which are reasons that may lead to a wrongful conviction. Research conducted in the United States has shown that about $25 \%$ of the persons primarily suspected for sexual offences were excluded as the perpetrator of the crime at the earliest stage of the proceedings thanks to DNA identification. ${ }^{33}$

${ }^{29}$ Saša Atanasov, Uloga svedoka u otkrivanju i dokazivanju krivičnog dela: doktorska disertacija, University of Priština temporarily settled in Kosovska Mitrovica, Faculty of Law, Kosovska Mitrovica 2016, 301

${ }^{30}$ At the main hearing at the Basic Court in Novi Sad (K 1596/16), the (female) witnesses were asked whether they could identify the perpetrator (a man) in the courtroom. At that moment, the defendant was sitting at the defense table and two uniformed members of the internal affairs stood beside him, while all other present persons in the courtroom were women, sitting at their places in the courtroom. Before the start of the main hearing, the witnesses saw the defendant in handcuffs being led by members of the police outside the courtroom.

${ }^{31}$ S. Krieger, 341-343

32 Jerome Frank, Barbara Frank Kristein, Not guilty, New York 1957, cited in Bruce A. MacFarlane, Wrongful Convictions: The Effect of Tunnel Vision and Predisposing Circumstances in the Criminal Justice System, Toronto 2008, 29-30; J. Gould, R. Leo, 851

${ }^{33}$ L. Weathered, 72 
Such behavior by investigative authorities is called a tunnel vision. In short, preoccupied with solving the case quickly, police officers turn their attention to the apparently best suspect, all the while ignoring all other clues and evidence. ${ }^{34}$ Tunnel vision can, however, occur at any point of the criminal justice process, and anyone can be infected with this "virus." 35 The public prosecutor or a judge may also be so satisfied with the defendant's confession that they overlook all evidence which challenges the accused's alleged culpability.

\subsection{False Confessions}

One of four wrongfully convicted persons in the US whose convictions were later overturned thanks to DNA evidence falsely confessed to committing the crime. ${ }^{36}$ Falsely confessing goes against the urge of self-preservation. ${ }^{37}$ However, there are two main groups of reasons behind this behavior.

The first group is related to punishment. Namely, in countries where there is a plea bargaining system, the defendant is offered a reduced sentence in exchange for a confession, a charge for a smaller offense, or a dismissal of some charges. ${ }^{38}$ The plea agreement implies direct negotiation between the public prosecutor and the defendant regarding penal sanctions, but the agreement requires confirmation of the court. ${ }^{39}$ In the states which allow the death penalty, in agreement with the prosecutor, the defendants confessed to offenses although they did not commit those crimes because the alternative was to go to trial and risk receiving the death sentence. On the other hand, in this way the defendants only received prison sentences. ${ }^{40}$ Even though the most rigorous sentence in Serbian criminal justice system is a 30 to 40 years long imprisonment, the issue of false confessions is still relevant, especially given that plea agreements are increasingly being used.

The second group of reasons relates to the psychological aspects of pre-trial confession. As a rule, the police are convinced that the suspect is guilty, so they

${ }^{34}$ Tim Prenzler, Police Corruption - Preventing Misconduct and Maintaining Integrity, Boca Raton 2009, 22, cited in Zoran Kesić, Radomir Zekavica, "Sloboda ili sigurnost: izbor koji nameće aktuelni rat protiv terorizma”, Naučno-stručni skup sa međunarodnim učešćem Evropske integracije: pravda, sloboda i bezbednost, Kriminalističko-policijska akademija, Belgrade, May 2016, Volume 3, Tara, 33

35 J. Gould, R. Leo, 851; L. Weathered, 72

${ }^{36}$ False Confessions \& Recording Of Custodial Interrogations, https://www.innocenceproject. org/causes/false-confessions-admissions/, April 3, 2019.

${ }^{37}$ Snežana Brkić, ,Priznanje okrivljenog kao tačka približavanja srpskog krivičnog procesnog prava anglosaksonskom pravu", Harmonizacija srpskog i mađarskog prava sa pravom Evropske unije, Novi Sad 2013, 309

${ }^{38}$ Ibid., 310

${ }^{39}$ Boriša Lečić, ,Sporazumi javnog tužioca i okrivljenog”, Zbornik radova Pravnog fakulteta u Novom Sadu, 2/2017, 388

${ }^{40}$ Veljko M. Delibašić, ,Sporazum javnog tužioca i okrivljenog o priznanju krivičnog dela”, Kultura polisa 32/2017, 363 
try to obtain its confession by using different tactics during the interrogation. ${ }^{41}$ The interrogation techniques employed by the police make it clear to the suspect that its guilt has already been established, that no one will believe its denials of guilt, and that continuing to deny its crimes will only aggravate its position. The suspect may comply with the police's demands because it simply feels tired and worn out after being questioned for hours or because it believes that the only way to be released is if it says what the police want to hear. ${ }^{42}$

In the Republic of Serbia, the statement of a defendant taken by the police can only be used as evidence in criminal proceedings if it is given in the presence of a defense lawyer. ${ }^{43}$ This gives less room for convictions based on false confessions given in the police station because the confession made by the suspect without the presence of counsel, which may occur as the result of psychological or even physical coercion, cannot be used in criminal proceedings. There are also provisions related to the plea agreement in order to prevent false confessions and false convictions: When this agreement is being concluded, the defendant must have a counsel present, and one of the conditions for accepting the agreement by the court is that there is additional evidence that does not contradict the defendant's confession. ${ }^{44}$ Finally, when the defendant confesses that it committed a crime, the competent authorities are obliged to continue to gather evidence about the perpetrator and the crime (only) if there is a reasonable doubt as to the accuracy of the confession or if the confession is incomplete, contradictory or unclear and contrary to other evidence. ${ }^{45}$

\subsection{Imperfect forensic scientific methods}

As science and technology developed, it became clear that some previously acceptable forensic methods were actually unreliable. For example, for a long time, microscopic hair analysis has been an acceptable way of connecting a suspect to a crime scene. Yet today, this forensic method is considered to be highly subjective and largely dependent on the capability of the competent authorities analyzing the samples. ${ }^{46}$ By DNA analysis, it is revealed that " 11 percent of the time, two hairs can be microscopically similar yet come from different people". ${ }^{47}$

${ }^{41}$ Such as implicit or explicit promises of leniency and implicit or explicit threats of harsher treatment in combination with other interrogation techniques such as accusation, repetition, attacks on denials, and claims that there is other evidence that incriminates the suspect even though such evidence does not actually exist, etc.

42 J. Gould, R. Leo, 846-847

${ }^{43} \mathrm{CPC}$, art. 289 pg. 4

${ }^{44}$ See CPC, art. 313 pg. 2 and art. 371 pg. 1 par. 3

${ }^{45} \mathrm{CPC}$, art. 88

${ }^{46}$ See J. Gould, R. Leo, 853

${ }^{47}$ Convicted defendants left uninformed of forensic flaws found by Justice Dept, https:// perma.cc/4M2B-LA3X, April 3, 2019. 
The AB0 blood type identification was also used to connect biological evidence to suspects. ${ }^{48}$ When speaking about this method, it should first be pointed out that it requires a larger blood sample in order to guarantee accurate testing, much larger than the one required for current DNA analysis. Consequently, the smaller the amount of blood tested, the more inaccurate the result will be. In addition, it is clear that matching a blood group does not mean identifying the suspect - approximately $40 \%$ of the world population has type 0 blood, about $30 \%$ type A blood, around $24 \%$ type $\mathrm{B}$, and about $6 \%$ type $\mathrm{AB}$ blood. ${ }^{49}$

Latent fingerprints left on different surfaces are still challenging to compare and identify. ${ }^{50}$ When it comes to non-computer fingerprint comparisons, it is performed by experts using the "ACE-V" procedure. This procedure involves 4 phases: analysis, comparison, evaluation and verification. Various studies attest to the errors inherent in this method. For example, when a group of experts was given 10 matches to verify -8 of which were correct and 2 incorrect, none of the experts noticed any incorrect matches. ${ }^{51}$ In 2007, a court in Baltimore, USA ruled that a forensic expert cannot identify the one suspect and exclude others using the "ACE-V" method. 52

\subsection{Inadequate Defense Representation}

The role of the defense counsel is to protect the innocent party from the mistakes made by other participants in the criminal proceedings. However, the convictions of innocents resulting from inadequate defense representation are still a reality,,$^{53}$ and this problem can be solved by raising the advocacy capacity, especially when it comes to the court appointed defense counsels.

The court appointed defense counsel must have expert knowledge on criminal case files or a moral character to refuse to represent someone if they believe they are not up to the task. They need to be acquainted with the criminal procedure and have as much experience as possible. These prerequisites should be taken into account when making the roster of court appointed defense counsels. In Serbia,

${ }^{48}$ See M. Šatrak et al., „Biološki tragovi na mjestu događaja”, Medicina fluminensis 54(2)/2018, 132

${ }^{49}$ World Population By Percentage Of Blood Types, https://www.worldatlas.com/articles/ what-are-the-different-blood-types.html, April 3, 2019.

${ }^{50}$ Nikola Milašinović, „Polimeri u kriminalistici - otkrivanje latentnih tragova otisaka prstiju - od ideje do praktične primene”, Nauka, bezbednost, policija 21(3)/2016, 133

${ }^{51}$ Anush Sankaran, Mayank Vatsa, Richa Singh, „Latent Fingerprint Matching: A Survey”, IEEE Access 2/2014, 988, table 2

52 STATE OF MARYLAND v. BRYAN ROSE (K06-0545), http://www.latent-prints.com/ images/State\%200f\%20Maryland\%20vs\%20Bryan\%20Rose\%20K06-0545.pdf, April 3, 2019.

${ }^{53}$ Gwen Jordan et al., „Contemporary Perspectives on Wrongful Conviction: An Introduction to the 2016 Innocence Network Conference, San Antonio, Texas, Hofstra Law Review 45/2016, 386; J. Gould, R. Leo, 855; S. Krieger, 354 
all interested attorneys can be added to this list. ${ }^{54}$ The financial aspect of court appointed defense counsel is a motivation for attorneys to actually dedicate themselves to assigned cases. ${ }^{55}$ However, due to the potential for making a nice profit, a large number of attorneys join the list and not all of them have the aforementioned qualities.

It should be kept in mind that criminal proceedings in the Republic of Serbia are designed in such a way that the defense and the prosecution are opposing parties and the court is kind of passive arbitrator. Therefore, the defense attorneys would have to be at least at the same level of expertise as the prosecutors. It is also worth mentioning that the legal concepts such as gathering of evidence and other materials by the defense, ${ }^{56}$ the cross-examination of witnesses, ${ }^{57}$ the hiring of professional consultant, ${ }^{58}$ etc. are called into question if, due to the incompetence of the defense counsel, they are not properly utilized.

\section{THE INNOCENCE PROJECTS}

Amid the struggle to abolish the death penalty, various tactics to draw public attention to the inadmissibility of the death penalty were explored. Traditional moral and religious arguments against capital punishment were not enough, prompting the proponents of the abolition of the death penalty to start using innocence as a messaging tactic focusing on wrongfully convicted persons and flaws of the criminal justice system to convince the public to support abolition. The bottom line was to convince the capital punishment supporters that the execution was too risky, as demonstrated by the wrongful execution of innocent individuals. ${ }^{59}$ At about the same time, a theology student, James C. McCloskey ${ }^{60}$ founded Centurion Ministries, an organization which provided help to the wrongfully convicted persons.$^{61}$ As part of his seminary field education work as a student chaplain at a New Jersey prison, McCloskey spent a lot of time talking to a convict who claimed to be innocent, which inspired him to dedicate his life to freeing the wrongfully convicted.$^{62}$ Centurion Ministries investigated the cases of the factually innocent,

${ }^{54}$ See ex. Official duty (Službena dužnost), http://akvogns.com/?page_id=342, April 3, 2019.

${ }^{55}$ See Tariff on fees and costs of attorneys (Tarifa o nagradama i naknadama troškova za rad advokata) Službeni glasnik RS, no. 121/2012

${ }^{56} \mathrm{CPC}$, art. 301

${ }^{57} \mathrm{CPC}$, art. 2 pg. 1 point 22

${ }^{58} \mathrm{CPC}$, art. 125

${ }^{59}$ S. Krieger, 360

${ }^{60}$ McCloskey was a Vietnam veteran and a successful businessman who decided to abandon his business life and enroll in Princeton Theological Seminary at age 37. R. Norris, 29

${ }^{61}$ S. Krieger, 361

${ }^{62}$ Centurion Innocence Movement, https://centurion.org/about-us/at-a-glance/, April 3, 2019. 
sentenced to life in prison or death ${ }^{63}$ In the first ten years of its existence, the organization freed 24 people. ${ }^{64}$ In 1992, Barry C. Scheck and Peter J. Neufeld, together with Benjamin N. Cardozo School of Law at the Yeshiva University in New York, USA, founded a non-profit organization - The Innocence Project. ${ }^{65}$ Since 1988, the founders worked as defense attorneys in cases where DNA samples have been used as evidence, soon becoming DNA specialists themselves. The Innocence Project initially only dealt with cases where a convict could have been exonerated on the basis of post-conviction DNA testing. The organization helped freeing of 364 people to date. ${ }^{66}$

The Innocence Project led to the creation of other similar organizations in cooperation with the law schools where students investigated cases under the mentorship of a professor or a lawyer. The functioning and goals of these later projects were basically the same as those of the "Innocence Project" and "Centurion Ministries." The only difference was as to whether only cases where there was DNA evidence were accepted for the research or were other cases accepted as well, and whether only cases where the death sentence or life imprisonment has been imposed were accepted or not. In any case, the two above-mentioned organizations impacted today's organizations of the innocence movement, with the help of journalists who drew the public's attention to wrongful convictions. All of this resulted in the exoneration of 2395 wrongfully convicted persons in the United States to date, 483 of which occurred due to the post-conviction DNA testing. ${ }^{67}$ In addition to case studies, organizations of this type also advocate a criminal justice reform to reduce the number of wrongful convictions.

Today, there are also organization associations that provide pro bono case investigation services with the aim to exonerate the wrongfully convicted and eliminate the causes of wrongful convictions, such as the Innocence Network ${ }^{68}$ (69 members, 56 of which are from the US) and the Red Innocente ${ }^{69}$ (15 members from 9 Latin America countries). In Europe, there are similar organizations in the United Kingdom, Ireland, France, the Netherlands, Spain, Italy, the Czech Republic and Poland, and when it comes to the Balkan countries, Croatia has plans to set up innocence projects in the near future. ${ }^{70}$

${ }^{63}$ G. Carroll, 673

${ }^{64}$ Centurion Innocence Movement, https://centurion.org/about-us/at-a-glance/, April 3, 2019.

${ }^{65}$ R. Norris, 31

${ }^{66}$ Innocence Project, https://www.innocenceproject.org/\#causes, April 3, 2019.

${ }^{67}$ The National Registry of Exonerations, http://www.law.umich.edu/special/exoneration/ Pages/Race-and-Wrongful-Convictions.aspx, February 26, 2019.

${ }^{68}$ About the Innocence Network, https://innocencenetwork.org/about/, April 3, 2019.

${ }^{69}$ Red Inocente, http://redinocente.org/, April 3, 2019.

${ }^{70}$ Science conferences and panels on this topic were held in Zagreb in 2015, in Split in 2016 and in Dubrovnik in 2018, after which it was announced that all prerequisites had been met in Croatia to officially launch the Innocence Project. See Innocence project launched in Croatia, 


\section{THE ROLE OF DNA TESTING IN FREEING THE WRONGFULLY CONVICTED}

After the British geneticist Alex Jeffreys discovered the techniques for DNA profiling, forensic science started using his methods both to incriminate suspects and to eliminate suspicion. After the DNA testing was conducted, in the first case, the DNA profile from the disputed biological sample, as a biological trace of unknown origin found at the crime scene, and the DNA profile from the undisputed biological sample, as the sample of a known person (the suspect), would match. In the second case, when DNA profiling is used to eliminate suspicions, the DNA profiles would not match. After DNA databases were created, the DNA profile of a disputed sample could be "run" through the database, thus immediately incriminating the individual whose DNA profile, stored in the database, matched the one found at the crime scene. DNA databases also play a significant role in DNA profiling upon completion of criminal proceedings: once it is confirmed that the DNA profile from the disputed sample and the DNA profile of the convicted person do not match, the actual perpetrator can be found by running the former sample through the database. The actual perpetrator was found in $50 \%$ of cases in which wrongfully convicted were exonerated based on post-conviction DNA analysis. In more than $3 / 4$ of these cases, the wrongfully convicted were exonerated with the help of the DNA database. However, in order to use DNA in this way, it is necessary to have the database of DNA profiles. In Serbia, there is only an informal database of DNA profiles within the laboratories performing DNA analysis ${ }^{71}$ and within the Ministry of Interior, ${ }^{72}$ while the official DNA database will be established by April $2020 .{ }^{73}$ On the other hand, some countries launched a DNA database over 20 years ago. ${ }^{74}$

We can, therefore, conclude that DNA analysis is, because of its accuracy rate, the most appropriate means of proving wrongful convictions. Letting an expert compare DNA profiles is much easier than pondering whether and why the

https://www.jutarnji.hr/vijesti/hrvatska/u-hrvatskoj-pokrenut-projekt-neduznosti-osudenim-osobama-omogucit-ce-preispitivanje-njihovih-predmeta-radi-utvrdivanja-neduznosti/7129305/ ?fbclid=IwAR1Yc34ien3z8xvxoZSL8Hr8IMx2WxSAo9UVJgz7v4C5k-XM9-Zlh-ZazJ0, April 3, 2019.

${ }^{71}$ Ištvan Feješ, „Zakonitost primene DNK analize u krivičnom postupku“, Zbornik radova Pravnog fakulteta u Novom Sadu 1-2/2008, 471

${ }^{72}$ Proposal of the Negotiating Position of the Republic of Serbia for the Intergovernmental Conference on the Accession of the Republic of Serbia to the European Union for Chapter 24 Justice, Freedom and Security, Belgrade 2016. http://eukonvent.org/wp-content/uploads/2016/07/ PG24-Pregovaracka-pozicija.pdf, 19

${ }^{73}$ See National DNA Register Act, Službeni glasnik RS, no. 24/2018, art. 10 pg. 1

${ }^{74}$ DNA databases were established back in 1994 and 1995 in the US and UK, in 1999 and 2000 in Austria, Germany, the Netherlands, Slovenia, Finland and Norway, and later on in Denmark, Switzerland, Croatia, Bulgaria, Montenegro and many other countries. Tijana Đurđević, „Zakon o nacionalnom DNK registru: čekajući odluku Ustavnog suda“, Pravni život 9/2018 Tom 1, 278 
witness misidentified the perpetrator. So why is the "DNA - non-DNA" exoneration ratio 1:5 - even in the US? ${ }^{75}$ The answer to this question should be sought in the conditions for post-conviction DNA analysis.

Firstly, for a DNA profile to be generated from the unknown sample, a biological trace must be left behind at the scene of the crime - which depends on the nature of the crime and the manner of its execution. Secondly, if biological traces are left behind, those traces must be available at the time when subsequent DNA analysis is ordered. In this regard, in the US, the length of biological trace evidence preservation varies depending on the state and crime. ${ }^{76}$ Florida law, for example, provides that in a case in which the death penalty is imposed, the evidence shall be maintained for 60 days after execution of the sentence. ${ }^{77}$ The Innocence Project revealed that (only) 29\% of closed cases from 2004 to 2015 were "closed" because of lost or destroyed evidence. ${ }^{78}$ Thirdly, post-conviction DNA testing must be permitted. "Justice for All Act" is an act that, among other things, regulates the issue of post-conviction DNA testing in the US and sets the terms under which it is permitted. ${ }^{79}$ Since the conditions are not too restrictive, it is said that it is actually surprising that not all prisoners in the US have already filed a petition for post-conviction DNA testing. ${ }^{80}$ And finally, since exonerations can occur only after a retrial, the law must provide for the possibility of retrial.

\section{POSSIBILITIES IN THE REPUBLIC OF SERBIA}

As noted in the preceding chapters, in the absence of precise research, we can assume that wrongful convictions are also happening in Serbia - the same as in every other country. Speaking about the opportunities afforded by DNA, the DNA analysis is covered by evidentiary action - obtaining samples and is used in criminal proceedings, while the country still does not have an official DNA database. Organizations such as innocence projects also do not exist in the Republic of Serbia.

\footnotetext{
${ }^{75}$ Exonerations by year: DNA and non-DNA, http://www.law.umich.edu/special/exoneration/ Pages/Exoneration-by-Year.aspx, 26.02.2019.

${ }^{76}$ See Evidence Retention Laws, http://victimsofcrime.org/docs/default-source/dna-resourcecenter-documents/evidence-retention-check-chart-9-5.pdf?sfvrsn=2, April 3, 2019.

77 The 2018 Florida Statutes, http://www.leg.state.fl.us/Statutes/index.cfm?App_mode=Display _Statute\&Search_String $=\& U R L=0900-0999 / 0925 /$ Sections $/ 0925.11 . h t m l$, April 3, 2019.

${ }^{78}$ DNA Exonerations in the United States, https://www.innocenceproject.org/dna-exonerations-in-the-united-states/, April 3, 2019.

${ }^{79}$ Justice for All Act of 2004, https://www.justice.gov/archive/olp/pdf/jfaa2004.pdf, April 3, 2019.

${ }^{80}$ Even for a guilty man, filing a petition for a post-conviction DNA testing could pay off if there is even the smallest chance that the DNA evidence found at the crime scene would not match his DNA, which could happen due to a technical error. G. Carroll, 698, 692
} 
In the context of the aforementioned assumptions for the exoneration of convicted persons through post-conviction DNA testing, it should be emphasized that there is no regulation on the preservation of evidence after the final verdict, nor any regulation on post-conviction DNA testing. An extraordinary legal remedy may be used - the request for reopening criminal proceedings, if new facts are presented or new evidence submitted, which, in themselves or in connection with earlier facts or evidence, may lead to rejection of the charges or an acquittal or a conviction according to a more lenient criminal law. ${ }^{81}$ It seems that, when the conditions for post-conviction DNA analysis are met, the request for reopening criminal proceedings could be placed under this category because the same fact in different circumstances, with different interpretation, using the opportunities afforded by the advancement of technology, may be crucial in proving innocence. ${ }^{82}$

The key problem, however, is that evidence is not preserved after the final verdict, ${ }^{83}$ therefore, neither is the evidence that contains biological traces from which DNA could be extracted. The CPC has an article ${ }^{84}$ which provides that keeping of records on the samples taken for DNA analysis ${ }^{85}$ their safekeeping and destruction is regulated by the act referred to in Article 279 of the Code. That Article states that the manner of keeping criminal records is regulated by the government. The criminal records have nothing to do with the crime scene samples, nor did the government regulate the manner of preserving the criminal record as per this Article. Therefore, there would be no evidence to compare with the DNA profile of the convicted person after the criminal proceedings were completed.

If this practice were to be changed now, if the permanent preservation of evidence or biological traces from the crime scene were to be regulated, this would not help the wrongfully convicted who are currently serving their sentences. It could possibly help those wrongfully convicted in the future, especially given that the national DNA database will soon be created and will be expanded over time. However, since DNA analysis is already being used as evidence in criminal proceedings, running the unknown DNA profile taken from the biological traces found at the crime scene subsequently through a larger base, will not help someone who was convicted on the basis of DNA evidence because its DNA profile already matched the DNA profile from the crime scene. If that person was wrongfully convicted, for example, because DNA had been tampered with, then post-con-

${ }^{81} \mathrm{CPC}$, art. 473 pg. 1 point 3

82 Davor Derenčinović, Sunčana Roksandić Vidlička, Marta Dragičević Prtenjača, "Projekti nedužnosti' i naknadna DNK vještačenja u Republici Hrvatskoj - moguća stvarnost ili nedostižna želja", Zbornik Pravnog fakulteta u Zagrebu 67(3-4)/2017, 387

${ }^{83}$ See CPC art. 147 pg. 1, art. 151 pg. 1, art. 153 pg. 4, art. 276 pg. 4 and 5; Judicial deposit, https://www.paragraf.rs/dnevne-vesti/050917/050917-vest2.html, 06.03.2019.

${ }^{84}$ CPC, art. 142 pg. 2

${ }^{85}$ Including the samples found at the crime scene or in some other place where the crime traces are located. 
viction DNA analysis would once again be of no help. Only future convictions based on other type of evidence, which does not include DNA samples, can benefit from this. However, if a biological trace was found at the crime scene, that trace would have been used as evidence in the criminal proceedings, so it seems that then we can only talk about post-conviction DNA analysis if the biological trace is found later on. And this is one of the reasons to request a retrial according to the current rules, as mentioned above. On the other hand, innocence projects, which would investigate cases no matter if the DNA evidence exist, would be useful both from a practical and a scientific and academic point of view, especially if they were organized with the support of law schools, which is, comparatively speaking, often the case.

\section{CONCLUSION}

When compared to previous forensic science methods, DNA analysis is undoubtedly a revolutionary technique. Its benefits include the expert examination of DNA traces in criminal proceedings, which is now universally accepted evidence. In countries with established DNA database, DNA is also used for discovering incriminating evidence against the suspect in pre-trial proceedings. Finally, DNA may also be used after the final judgment to exonerate the wrongfully convicted.

With it comes to the latter, post-conviction DNA analysis is just one way of determining a wrongful conviction. When conducted by an expert, it is the most reliable and the simplest method, however, it assumes that biological traces are found at the scene of the crime and that those traces are preserved until the time the post-conviction DNA analysis is requested. Even in the US, where the biological traces are preserved even after the final verdict, "DNA - Non-DNA" exonerations have a ratio of 1:5. In countries where the evidence is not kept after the final verdict, one of which is the Republic of Serbia, as long as that is the case, despite the possibility of using an extraordinary legal remedy that would allow a retrial, post-conviction DNA analysis simply cannot be conducted.

Other ways of determining a wrongful conviction and finally exonerating the wrongfully convicted are based on the traditional concept of investigating cases, finding evidence in favor of the convicted an then seeking a retrial. In this way, the largest number of wrongful convictions in the world has been overturned. Yet the majority of wrongful convictions have never been overturned. In order to achieve the goal of criminal proceedings to prevent the conviction of any innocent person, it must be first acknowledged that the criminal justice system makes mistakes. Then, the causes of conviction of the innocent must be investigated and should be eliminated through judicial reform. Finally, one should think about whether and in what way the current as well as all future convicts punished for other people's 
actions, can be helped. Organizations such as the "Innocence Project," which are commonplace in the United States and no longer represent a rare sight in European countries, would make a significant contribution to these activities.

\section{REFERENCES}

Adnan Fazlić, Irma Deljkić, „Multidisciplinarni pristup provođenju radnje prepoznavanja osoba u kriminalističkoj istrazi”, Kriminalistička teorija i praksa 4(2)/ 2017 About the Innocence Network, https://innocencenetwork.org/about/, 03.04.2019.

America's Guilty Plea Problem: Chris Ochoa, https://www.youtube.com/watch?v= AU65911-BbU, 03.04.2019.

Anush Sankaran, Mayank Vatsa, Richa Singh, „Latent Fingerprint Matching: A Survey”, IEEE Access 2/2014

Boriša Lečić, „Sporazumi javnog tužioca i okrivljenog”, Zbornik radova Pravnog fakulteta u Novom Sadu, 2/2017

Bruce A. MacFarlane, Wrongful Convictions: The Effect of Tunnel Vision and Predisposing Circumstances in the Criminal Justice System, Toronto 2008

Veljko M. Delibašić, „Sporazum javnog tužioca i okrivljenog o priznanju krivičnog dela", Kultura polisa 32/2017

Gilles Perrault: "L'honneur de la justice est d'admettre qu'elle peut se tromper", https:// www.humanite.fr/node/241053, 06.03.2019.

Gwen Jordan et al., „Contemporary Perspectives on Wrongful Conviction: An Introduction to the 2016 Innocence Network Conference, San Antonio, Texas, Hofstra Law Review 45/2016

Gwendolyn Carroll, „Proven Guilty: An Examination of the Penalty-Free World of Post-Conviction DNA Testing", The Journal of Criminal Law and Criminology 97(2)/2007

Davor Derenčinović, Sunčana Roksandić Vidlička, Marta Dragičević Prtenjača, „,,Projekti nedužnosti” i naknadna DNK vještačenja u Republici Hrvatskoj - moguća stvarnost ili nedostižna želja”, Zbornik Pravnog fakulteta u Zagrebu 67(3-4)/2017

Daniel S. Medwed, Prosecution Complex: America's Race to Convict, and Its Impact on the Innocent, New York 2012

DNA Exonerations in the United States, https://www.innocenceproject.org/dna-exonerations-in-the-united-states/, 03.04.2019.

Ellen Yaroshefsky, „Ethics and Plea Bargaining - What's Discovery Got to Do With It”, Criminal Justice 28/2008

Ernest van den Haag, „,The Death Penalty Once More”, UC Davis Law Review 18(4)/1985

Evidence Retention Laws, http://victimsofcrime.org/docs/default-source/dna-resource-center-documents/evidence-retention-check-chart-9-5.pdf?sfvrsn=2, 03.04.2019.

Exonerations by year: DNA and non-DNA, http://www.law.umich.edu/special/exoneration/Pages/Exoneration-by-Year.aspx, 26.02.2019.

Eyewitness Misidentification, https://www.innocenceproject.org/causes/eyewitness-misidentification/, 03.04.2019. 
Zakon o nacionalnom DNK registru, Službeni glasnik RS, br. 24/2018

Zakonik o krivičnom postupku - ZKP, Službeni glasnik RS, br. 72/2011, 101/2011, 121/2012, 32/2013, 45/2013 i 55/2014

Zoran Kesić, Radomir Zekavica, ,Sloboda ili sigurnost : izbor koji nameće aktuelni rat protiv terorizma”, Naučno-stručni skup sa međunarodnim učešćem Evropske integracije: pravda, sloboda i bezbednost, Kriminalističko-policijska akademija, Beograd, Maj 2016, Tom 3, Tara

Ivan Ilić, Ispitivanje činjenične osnove krivične presude : doktorska disertacija, Univerzitet u Nišu, Pravni Fakultet, Niš 2018

Ištvan Feješ, ,Zakonitost primene DNK analize u krivičnom postupku“, Zbornik radova Pravnog fakulteta u Novom Sadu 1-2/2008

Innocence Project - Chris Ochoa, https://www.youtube.com/watch?v=0xJlsxCGw9w, 03.04.2019.

Innocence Project, https://www.innocenceproject.org/\#causes, 03.04.2019.

Innocents Database, http://forejustice.org/idbinternational.html, 03.04.2019.

Jon B. Gould, Richard A. Leo, ,One Hundred Years Later: Wrongful Convictions after a Century of Research", The Journal of Criminal Law and Criminology 100(3)/2010

Justice for All Act of 2004, https://www.justice.gov/archive/olp/pdf/jfaa2004.pdf, 03.04.2019.

List of miscarriage of justice cases, https://en.wikipedia.org/wiki/List_of_miscarriage of justice cases, 03.04.2019.

Lynne Weathered, ,Investigating Innocence - The Emerging Role of Innocence Projects in the Correction of Wrongful Conviction in Australia", Griffith Law Review 12(1)/2003

M. Šatrak et al., „Biološki tragovi na mjestu događaja”, Medicina fluminensis 54(2)/2018

Michael D. Risinger, ,Innocents Convicted: An Empirical Justified Factual Wrongful Conviction Rate" The Journal of Criminal Law \& Criminology 97(3)/2007

Nikola Milašinović, „Polimeri u kriminalistici - otkrivanje latentnih tragova otisaka prstiju - od ideje do praktične primene", Nauka, bezbednost, policija 21(3)/2016

Predlog Pregovaračke pozicije Republike Srbije za Međuvladinu konferenciju o pristupanju Republike Srbije Evropskoj uniji za poglavlje 24 - „Pravda, sloboda i bezbednost", Beograd 2016. http://eukonvent.org/wp-content/uploads/2016/07/ PG24-Pregovaracka-pozicija.pdf

Red Inocente, http://redinocente.org/, 03.04.2019.

Richard Danziger, https://www.law.umich.edu/special/exoneration/Pages/casedetail. aspx? caseid=3152, 03.04.2019.

Robert J. Norris, ,Framing DNA: Social Movement Theory and the Foundations of the Innocence Movement", Journal of Contemporary Criminal Justice 33(1)/ 2017

Ronald C. Huff, Martin Killias, „Wrongful Conviction: Conclusions from an International Overview", Wrongful Conviction: International Perspectives on Miscarriages of Justice (eds. Ronald C. Huff, Martin Killias), New York 2013

Saša Atanasov, Uloga svedoka u otkrivanju i dokazivanju krivičnog dela: doktorska disertacija, Univerzitet u Prištini sa privremenim sedištem u Kosovskoj Mitrovici, Pravni fakultet, Kosovska Mitrovica 2016

Službena dužnost, http://akvogns.com/?page_id=342, 03.04.2019. 
Snežana Brkić, „Priznanje okrivljenog kao tačka približavanja srpskog krivičnog procesnog prava anglosaksonskom pravu", Harmonizacija srpskog i mađarskog prava sa pravom Evropske unije, Novi Sad 2013

Sudski depozit, https://www.paragraf.rs/dnevne-vesti/050917/050917-vest2.html, 06.03.2019.

S. R. Grossa et al, „Rate of false conviction of criminal defendants who are sentenced to death", PNAS, 11(20)/2014

Sir William Blackstone, https://www.britannica.com/biography/William-Blackstone, 03.04.2019.

STATE OF MARYLAND v. BRYAN ROSE (K06-0545), http://www.latent-prints. com/images/State\%20Of\%20Maryland\%20vs\%20Bryan\%20Rose \%20K060545.pdf, 03.04.2019.

Stephanie Roberts, Lynne Weathered, „Assisting the Factually Innocent: The Contradictions and Compatibility of Innocence Projects and the Criminal Cases Review Commission", Oxford Journal of Legal Studies 29(1)/2009

Steven A. Krieger, „Why Our Justice System Convicts Innocent People, and the Challenges Faced by Innocence Projects Trying to Exonerate Them", New Criminal Law Review 14(3)/2011

Tarifa o nagradama i naknadama troškova za rad advokata, Službeni glasnik RS, br. $121 / 2012$

Tijana Đurđević, „Zakon o nacionalnom DNK registru: čekajući odluku Ustavnog suda", Pravni život 9/2018 Tom 1

The 2018 Florida Statutes, http://www.leg.state.fl.us/Statutes/index.cfm?App_mode= Display_Statute\&Search_String=\&URL=0900-0999/0925/Sections/0925.11. html, 03.04.2019.

The National Registry of Exonerations, http://www.law.umich.edu/special/exoneration/ Pages/Race-and-Wrongful-Convictions.aspx, 03.04.2019.

U Hrvatskoj pokrenut projekat nedužnosti, https://www.jutarnji.hr/vijesti/hrvatska/ u-hrvatskoj-pokrenut-projekt-neduznosti-osudenim-osobama-omogucit-ce-preispitivanje-njihovih-predmeta-radi-utvrdivanja-neduznosti/7129305/?fbclid=IwAR1Yc34ien3z8xvxoZSL8Hr8IMx2WxSAo9UVJgz7v4C5k-XM9-Zlh-ZazJ0, 03.04.2019.

False Confessions \& Recording Of Custodial Interrogations, https://www.innocenceproject.org/causes/false-confessions-admissions/, 03.04.2019.

Hugo Adam Bedau, Michael L. Radelet, „Miscarriages of Justice in Potentially Capital", Stanford Law Review, 40(1)/1987

Centurion Innocence Movement, https://centurion.org/about-us/at-a-glance/, 03.04.2019.

Chris Ochoa: A True Story of a False Confession, https://www.youtube.com/watch?v= 9aI8AqB TLA, 03.04.2019.

Chrisje Brants, „Vulnerability of Dutch Criminal Procedure to Wrongful Conviction”, Wrongful Conviction: International Perspectives on Miscarriages of Justice (eds. Ronald C. Huff, Martin Killias), New York 2013

Convicted defendants left uninformed of forensic flaws found by Justice Dept, https:// perma.cc/4M2B-LA3X, 03.04.2019.

World Population By Percentage Of Blood Types, https://www.worldatlas.com/articles/ what-are-the-different-blood-types.html, 03.04.2019. 
Tijana V. Đurđević, student doktorskih studija

Univerzitet u Novom Sadu

Pravni fakultet u Novom Sadu

durdevict@yahoo.com

\section{Da li je DNK analiza ključ slobode za pogrešno osuđene?}

Sažetak: Podatak da je nakon otkrića DNK i mogućnosti identifikacije lica na osnovu DNK zahvaljujući naknadnoj DNK analizi oslobođeno blizu pet stotina pogrešno osuđenih inspirisao nas je da istražimo pitanje pogrešnih osuda i ulogu DNK analize u njihovom ispravljanju. U članku se najpre razmatraju pojam $i$ posledice, procene o učestalosti i uzroci pogrešnih osuda, a potom se daje prikaz pojedinih organizacija koje se u uporednoj praksi bave istraživanjem slučajeva pogrešnih osuda. Nadalje se objašnjava uloga DNK u oslobađanju pogrešno osuđenih kao i pretpostavke koje moraju postojati da bi se osude mogle ispraviti na ovaj način. Na samom kraju članka razmatraju se trenutne mogućnosti $i$ perspektive u našoj zemlji u vezi sa ispravljanjem pogrešnih osuda putem naknadne DNK analize, ali i na druge načine.

Ključne reči: krivični postupak, pogrešno osuđeni, DNK, projekti nevinosti.

Datum prijema rada: 23.04.2019. 